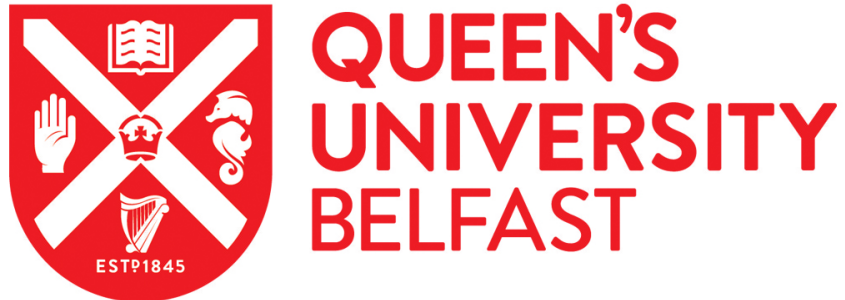

\section{Influencing effect of heat-treatment on radon emanation and exhalation characteristic of red mud}

Sas, Z., Szántó, J., Kovács, J., Somlai, J., \& Kovács, T. (2015). Influencing effect of heat-treatment on radon emanation and exhalation characteristic of red mud. Journal of Environmental Radioactivity, 148, 27-32. https://doi.org/10.1016/j.jenvrad.2015.06.002

Published in:

Journal of Environmental Radioactivity

Document Version:

Peer reviewed version

Queen's University Belfast - Research Portal:

Link to publication record in Queen's University Belfast Research Portal

Publisher rights

(C) 2015 Elsevier Ltd . This manuscript version is made available under the CC-BY-NC-ND 4.0 license

$\mathrm{http}: / /$ creativecommons.org/licenses/by-nc-nd/4.0/ which permits distribution and reproduction for non-commercial purposes, provided the author and source are cited.

\section{General rights}

Copyright for the publications made accessible via the Queen's University Belfast Research Portal is retained by the author(s) and / or other copyright owners and it is a condition of accessing these publications that users recognise and abide by the legal requirements associated with these rights.

Take down policy

The Research Portal is Queen's institutional repository that provides access to Queen's research output. Every effort has been made to ensure that content in the Research Portal does not infringe any person's rights, or applicable UK laws. If you discover content in the Research Portal that you believe breaches copyright or violates any law, please contact openaccess@qub.ac.uk. 


\title{
INFLUENCING EFFECT OF HEAT-TREATMENT ON RADON EMANATION AND EXHALATION CHARACTERISTIC OF RED MUD
}

\author{
Z. Sas ${ }^{1}$, J. Szántó ${ }^{1}$, J. Kovács ${ }^{2}$, J. Somlai ${ }^{1}$, T. Kovács ${ }^{1, *}$ \\ ${ }^{1}$ Institute of Radiochemistry and Radioecology, University of Pannonia, POB. 158., H-8201, \\ Veszprém, Hungary \\ ${ }^{2}$ Institute of Environmental Engineering, University of Pannonia, POB. 158., H-8201, \\ Veszprém, Hungary
}

*Corresponding author: kt@almos.uni-pannon.hu

*Institute of Radiochemistry and Radioecology, University of Pannonia, P.O. Box 158, H8201 Veszprém, Hungary

\section{Abstract}

The reuse of industrial by-products is important for members of numerous industrial sectors. However, though the benefits of reuse are evident from an economical point of view, some compounds in these materials can have a negative effect on users' health.

In this study, the radon emanation and exhalation features of red mud were surveyed using heattreatment $\left(100\right.$ to $\left.1200^{\circ} \mathrm{C}\right)$. As a result of the $1200^{\circ} \mathrm{C}$-treated samples, massic radon exhalation capacity reduced from $75 \pm 10 \mathrm{mBq} \mathrm{kg}^{-1} \mathrm{~h}^{-1}$ to $7 \pm 4 \mathrm{mBq} \mathrm{kg}^{-1} \mathrm{~h}^{-1}$, approximately $10 \%$ of the initial exhalation rate.

To find an explanation for internal structural changes, the porosity features of the heat-treated samples were also investigated. It was found that the cumulative pore volume reduced significantly in less than $100 \mathrm{~nm}$, which can explain the reduced massic exhalation capacity in the high temperature treated range mentioned above.

SEM snapshots were taken of the surfaces of the samples as visual evidence for superficial morphological changes. It was found that the surface of the high temperature treated samples had changed, proving the decrement of open pores on the surface.

Keywords: red mud, heat-treatment, radon exhalation, by-product, building material industry, additional material

\section{Introduction}

The inherent compounds of building materials can have a negative effect on human health. Today, the reuse of red mud in the building material industry has developed into both a public discussion and a debate among scientists and the industrial sector. To avoid the contingent negative effects caused by the reuse of this material and its inherent properties, different possibilities from a range of perspectives have to be considered. 
Recently, several studies have addressed the reuse possibilities of industrial by-products reasons that are disposed in waste reservoirs. As a result of the depletion of raw materials, the reuse of these materials has become the focal point of interest. On the one hand, reuse could reduce the environmental impact of deposited by-products, while the health risks of doing so can be prevented by the dusting of reservoirs in the vicinity of inhabited areas (Kovács et al. 2012; Karangelos et al. 2004).

The integration of by-products into other industries as secondary raw materials can be beneficial for companies from an economical perspective. However, the reuse of new types of synthetic materials has raised concerns among authorities, the public and researchers (Gelencsér et al. 2011; Winkler 2014). In some cases, certain components of raw materials can remain in the by-product and pose an elevated risk to humans. During the applied Bayer-process, for example, the aluminium industry produces large amount of alkali red mud, wherein a significant amount of natural radionuclide content of bauxite remains.

The natural radionuclide content of manufactured building material products (e.g. Szabó et al. 2013; Trevisi et al. 2012, Cosma et al. 2013) contributes to natural background radiation in two ways. On the one hand, the gamma radiation of the primordial radionuclides (K-40 and daughter elements of U-238, Th-232) increases the external gamma dose rate. On the other hand, the inhaled Rn-222, Rn-220 and their progenies augment the risk of the evolution of lung cancer (UNSCEAR 2008; WHO 2009). Radon is a radioactive noble gas that originates from Ra-226 content with a relatively long half-life (3.82 d). This time can be enough to get out of the matrix into the pore space and into the air as well, depending on the condition of the containing matrix.

While the alpha particle ejected from the Ra-226 isotope as a result of alpha decay, the daughter element (Rn-222) is recoiled and can be released into the pore space or embedded in adjacent particles, owing to its kinetic energy (86 keV) remaining as the result of energy from alpha decay (Ishimori et al. 2013).

The emanation coefficient or emanation power is defined as the quantitative rate of the released radon from the crystal structure into the open pore space to the total amount of the generated in the matrix. Thus, many factors determine the amount of the emanated radon such as the variation of the radium concentration of particles, density, homogeneity in radium distribution, grain size, volume of pore space and moisture content (Ishimori et al. 2013).

Only the emanated radon has a chance to exhale from the open pores of the matrix into the air depending on the several influencing parameters such as, porosity, temperature, moisture content, pressure conditions and thickness, amongst others.

The determination of radon exhalation has not standardized in international level due to difficulties of "ideal” conditions of measurement circumstances (Kovler et al. 2011)

The radon exhalation is the radon activity that diffuses per unit of time from a material to the air surrounding the material, in $\mathrm{Bq} \mathrm{s}^{-1}$ defined in NEN 5699:2001 EN standard (Netherlands Standardization Institute (NEN) 2001). By dividing the radon exhalation rate by either the area of the 
exhaling surfaces or by the mass of the sample, the areic (radon flux $\mathrm{Bq} \mathrm{m} \mathrm{m}^{-2} \mathrm{~s}^{-1}$ ) and massic radon exhalation rates $\left(\mathrm{Bq} \mathrm{kg}{ }^{-1} \mathrm{~s}^{-1}\right)$ can be calculated. The exhalation rate related to mass should depend on several factors, such as porosity and geometry (especially on the thickness) of the sample.

It is possible to ensure an extreme case when the thickness of the samples is very small against the diffusion length of radon. In that case only the sample characteristics (Ra-226 content, emanation coefficient, and the amount of the sample) have influence on exhalation rate (López-Coto et al. 2009). It means all the emanated radon can exhale from the matrix and the massic radon exhalation rate can be determined.

Generally, the diffusion length in case of porous materials is higher than $40 \mathrm{~cm}$ (Keller et al. 2001, Mujahid et al. 2005) (e.g. porous soil and brick $40 \mathrm{~cm}$, gypsum $110 \mathrm{~cm}$, sand $200 \mathrm{~cm}$ ). Owing to that fact, this assumption can be used for comparison (Kovler et al. 2005) if the sample thickness of porous material is less than $5 \mathrm{~cm}$.

The above-mentioned circumstances had a significant effect on the final exhalation capacity of the materials. For this reason, the determination of Ra-226 content is not sufficient for characterizing the raw material, since radon emanation and the exhalation greatly depends on internal structure changes occurring as a result of the applied processing technique (Kovács et al. 2012; López-Coto et al. 2009; Tuccimei et al. 2006; Prasad et al. 2012; Cosma et al. 2001; Sas et al. 2012). Several studies have dealt with the usability of red mud in the building material industry in terms of thermal behaviour (Zhang et al. 2011; Sglavo et al. 2000a, 2000b; Pontikes et al. 2007, 2009; Yao et al. 2013).

\subsection{The aims of this study:}

- Determination of the emanation- and massic exhalation-modifying effects of heat treatment on red mud samples as a result of applied heat-treatment.

- Determination of the main internal structural changes of the heat-treated samples (pore space, specific surface, superficial morphology determination with SEM)

- Comparison of the heat-treated red mud massic exhalation characteristics and the obtained internal structural changes

\section{Material and methods}

\subsection{Sampling and sample preparation}

The investigated red mud sample was collected from a 1 to $2 \mathrm{~m}$ depth of red mud reservoirs in Ajka (Hungary). The samples were heated to a constant mass at a temperature of $105 \pm 3^{\circ} \mathrm{C}$, grinded under $0.63 \mathrm{~mm}$ and homogenized. In order to obtain Ra-226 activity concentration of the sample the powdered red mud was put into aluminium Marinelli vessel, weighted, sealed and stored during 27 days to reach the secular equilibrium between Rn-222 and its progenies. 
For massic exhalation measurement spherical-shaped red mud samples were prepared. The size of the samples was $0.5 \mathrm{~cm}$ diameter to ensure exhalation condition which was not dependent from sample.

This is the reason why the effect diffusion length can be neglected under presented measurement conditions. Of course the inhomogeneity of the samples also can have effect but because of the low sample thickness and the continuous and slow warm up program of the kiln the balanced internal structure changes of the samples was ensured. Furthermore glazing material was not used which could cardinally change the surface of treated samples. This is the reason why all the emanated radon can exhale from the prepared matrix.

To ensure the representative conditions, parallel procedures were carried out. The total amount of prepared sample was divided into two equal parts (sample "A" and sample "B"). In the case of the heat-treatments, samples A and B were treated in a pre-programmed kiln (one hour heating, three hours constant heat; following on, cooled down to room temperature by itself. Following treatment in certain temperatures, the massic radon exhalation features of the samples were measured. Thereafter, the samples were again treated at a higher temperature. Altogether, seven different temperatures were used ranging from 100 to $1200^{\circ} \mathrm{C}\left(100,200,400,600,800,1000\right.$ and $\left.1200{ }^{\circ} \mathrm{C}\right)$. All the massic exhalation measurements were performed in room temperature after heat-treatments.

\subsection{Gamma spectrometry}

The Ra-226 activity concentration was determined via its progenies (295 keV of Pb-214 and $609 \mathrm{keV}$ of $\mathrm{Bi}-214$ ) reached the secular equilibrium by gamma spectrometry used a semiconductor HPGe detector (ORTEC GMX40-76, efficiency of $40 \%$ ). The data and spectra were recorded by ORTEC DSPEC LF 8196 MCA. The system was calibrated with IAEA soil reference material.

\subsection{Determination of exhalation rate and emanation factor}

The prepared and heat-treated samples were surveyed from the massic exhalation point of view. After sample preparation, $0.5-0.5 \mathrm{~kg}$ of red mud spheres was enclosed in a glass accumulation chamber covered by a metal cap. The homogeneity of the inner air was ensured by a small size $12 \mathrm{~V}$ DC ventilator, which was placed inside the chamber. The chamber volume was more than ten times higher than the sample volume to avoid the back diffusion of radon into the sample pores (Tuccimei et al. 2006; $\underline{\text { Prasad }}$ et al. 2012; Cosma et al. 2001).

The radon leakage features of the accumulation chambers were surveyed with the help of a PYLON RN 2000A-type passive radon source. All the accumulation chambers were filled with Rn-222 gas. The radon activity concentration in the chambers were measured with AlphaGUARD 2000 portable radon monitor under close loop circulation. After measurement the valves of the chamber were closed during 3 days and the monitor was removed from the sampling loop. The remaining activity 
concentrations in the cambers were measured again and volume correction (required because of the dilution effect of sampling kit volume, e.g. pipes, detector chamber, desiccant) was applied. Finally, the measured and corrected activity concentration was compared with calculated activity concentration derived from initial radon concentration. The leakage rates of the prepared chambers were lower than $1 \%$.

Before measurements the chambers were purged with radon-free $\mathrm{N}_{2}$ gas prior to the accumulation to reduce the initial radon concentration $\left(\mathrm{C}_{0}\right)$ to zero. Following the accumulation period, the chamber was connected to a closed loop system (Fig. 1), wherein the radon increment was flowed by a radon-proof pump and passed through a desiccant and an air filter into an AlphaGUARD 2000 portable radon monitor. The detector of the measurements system was a pulse ionization chamber with an active volume of $0.56 \mathrm{dm}^{3}$. The samples were surveyed under "10 min FLOW MODE".

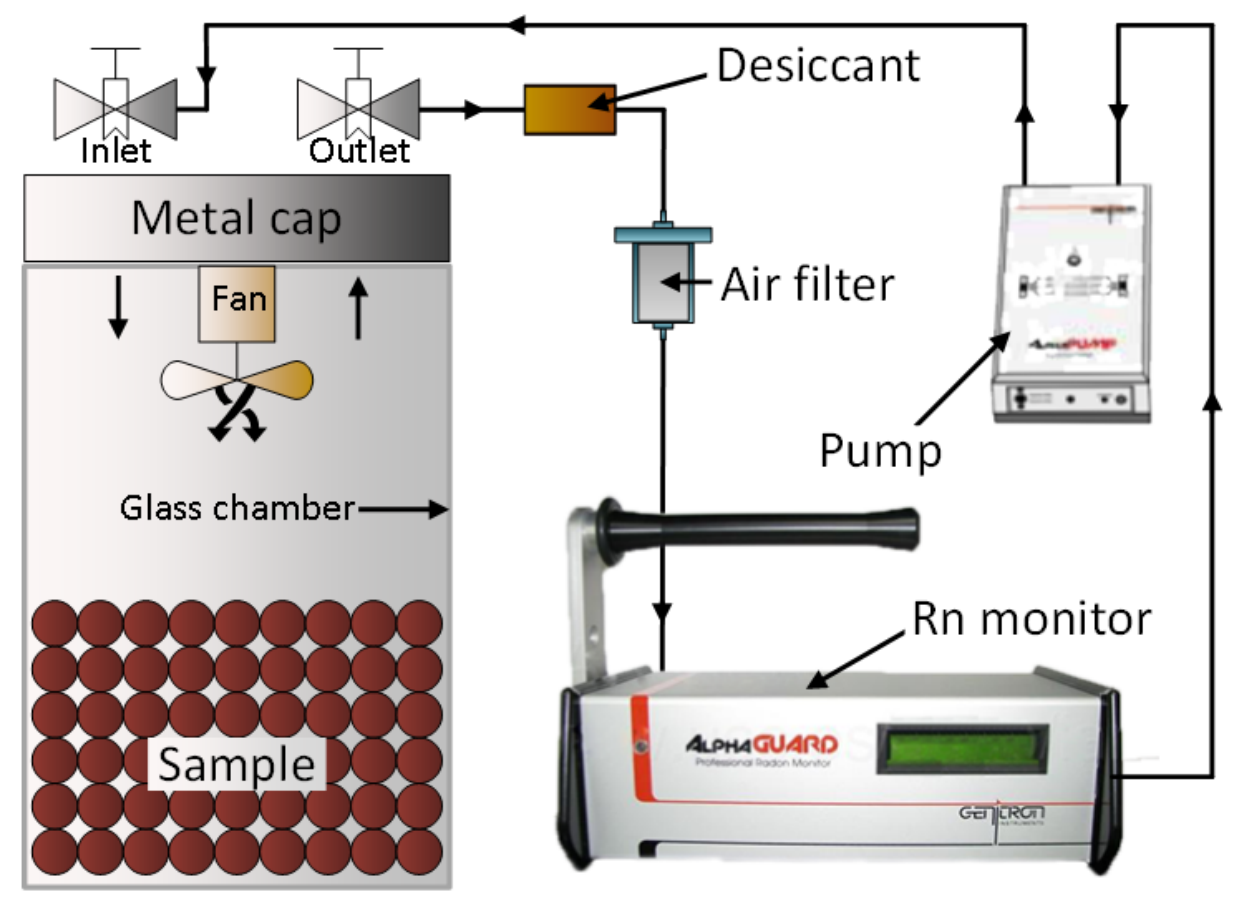

Fig. 1. Closed loop exhalation sampling system

Beside the radon the thoron also obtain access to the detector chamber. To avoid the disturbing effect on airflow caused by the thoron content (cannot be distinguished by the instrument), the airflow was ceased after 20 minutes, while the measurements were continued for another 40 more minutes. The thoron contend decayed after the pump was stopped (within 10 minutes) and the radon content was obtained only after the $30-60$ minutes period as a result of the measured average activity concentration.

The massic radon exhalation could be calculated using the following formula (Kovler 2006; Petropolous et al. 2001; Quindos et al. 1994):

$$
\mathrm{E}_{\text {Mass }}=\mathrm{C}_{0} \cdot \mathrm{e}^{-\lambda \cdot \mathrm{t}}+\frac{\mathrm{C} \cdot \mathrm{V}}{\mathrm{m} \cdot \mathrm{t}} \cdot \frac{\lambda \cdot \mathrm{t}}{1-\mathrm{e}^{-\lambda \mathrm{t}}}
$$


Where:

- $\mathrm{C}_{0}=$ initial radon concentration $\left[\mathrm{Bq} / \mathrm{m}^{3}\right]$

- $\quad \mathrm{C}=$ accumulated radon concentration $\left[\mathrm{Bq} / \mathrm{m}^{3}\right]$

- $\quad \mathrm{E}_{\text {Mass }}=$ massic exhalation rate $\left[\mathrm{mBqkg}^{-1} \mathrm{~h}^{-1}\right]$

- $\mathrm{t}=$ accumulation time $[\mathrm{h}]$

- $\quad \mathrm{V}=$ volume of the accumulation kit $\left[\mathrm{m}^{3}\right]$

- $\mathrm{m}=$ mass of the sample $[\mathrm{kg}]$

- $\lambda=$ decay constant of radon $\left[\mathrm{h}^{-1}\right]$

\subsection{Specific surface, pore volume measurements}

The exhalation behaviour of porous materials and the internal structure parameters, such as specific surface, pore volume and pore size distribution are interdependent features. The porosity features of the samples were measured using a combined method. The micro- $(<2 \mathrm{~nm})$ and mezo-porosity (2 to 300) were investigated with a Micromeritics ASAP 2000 device. The surface-adsorbed gases were removed with a vacuum $(\mathrm{p}<0.1 \mathrm{mmHg})$ at $100^{\circ} \mathrm{C}$. Then, adsorption and desorption isotherms for nitrogen gas were measured at the temperature of liquid nitrogen. According to the BET theory (Brunauer-EmmettTeller), the specific surface of the samples was calculated (Brunauer et al. 1938).

The macro-porosity interval (above $300 \mathrm{~nm}$ ) was investigated with the help of a SMH6 mercury poremeter. Samples (1 to $5 \mathrm{~g}$ ) were placed in a vacuum ( $\mathrm{p}<0.1 \mathrm{mmHg}$ ) at room temperature. The measuring receptacle was filled with mercury and the change in $\mathrm{Hg}$ level in the capillary was recorded against pressure (0 to $760 \mathrm{mmHg}$ ) (Jobbágy et al. 2009). Finally, the results were merged to gain comprehensive data about the internal structure of heat-treated red mud samples.

\subsection{Superficial morphology measurement}

The superficial morphological conversion of the heat-treated samples was observed with a Phillips XL 30 ESEM. This device was suitable for taking snapshots during the procedure, when the electron beam was in a vacuum and the sample holder chamber was under pressure ( 0.1 to $40 \mathrm{mmHg}$ ). The dryness of the sample and the conductive layer coverage was not necessary. In order to find the optimal resolution, the applied magnification varied between 100x and 1000x. ESEM pictures were taken from every heat interval to follow the state of the surface. 


\section{Results and discussion}

\subsection{Gamma spectrometry and radon exhalation measurement}

The Ra-226 content of investigated red mud sample was $182 \pm 18 \mathrm{~Bq} / \mathrm{kg}$ which is approximately six times higher than the world average of soils' (32 Bq/kg)' published in UNSCEAR 2008 Report (UNSCEAR 2010). The obtained result was the lowest compared of .red mud samples originated from other red mud reservoirs of Ajka (Sas et al. 2015).

On the basis of the obtained massic exhalation results, the massic exhalation characteristics of the heattreated samples can be illustrated (Fig. 2). The results of the parallel measurements clearly proved that the massic exhalation features greatly depended on the applied heat. The initial massic exhalation capacity $\left(75 \pm 10 \mathrm{mBq} \mathrm{kg}{ }^{-1} \mathrm{~h}^{-1}\right)$ was increased by $30 \%\left(103 \pm 13 \mathrm{mBq} \mathrm{kg}^{-1} \mathrm{~h}^{-1}\right)$, which can likely be explained by the departure of the structural water content. As a result of the modification that occurred in the structural condition, the rearrangement of the porosity conditions was likely.

In the next temperature step, the massic exhalation began to reduce at a continuous rate. In the case of $800^{\circ} \mathrm{C}$, the massic exhalation capacity reduced to less than $35 \pm 8 \mathrm{mBq} \mathrm{kg}{ }^{-1} \mathrm{~h}^{-1}$ (approximately $50 \%$ of the initial capacity), whilst in the case of $1200^{\circ} \mathrm{C}$, the measured average value was only $7 \pm 4$ $\mathrm{mBq} \mathrm{kg}{ }^{-1} \mathrm{~h}^{-1}$, which was approximately $10 \%$ of the initial value.

The emanation coefficient of investigated samples were calculated from obtained massic exhalation results. (Kovler et al. 2005) The obtained emanation factors in function of applied heat treatment are illustrated in Fig 2.

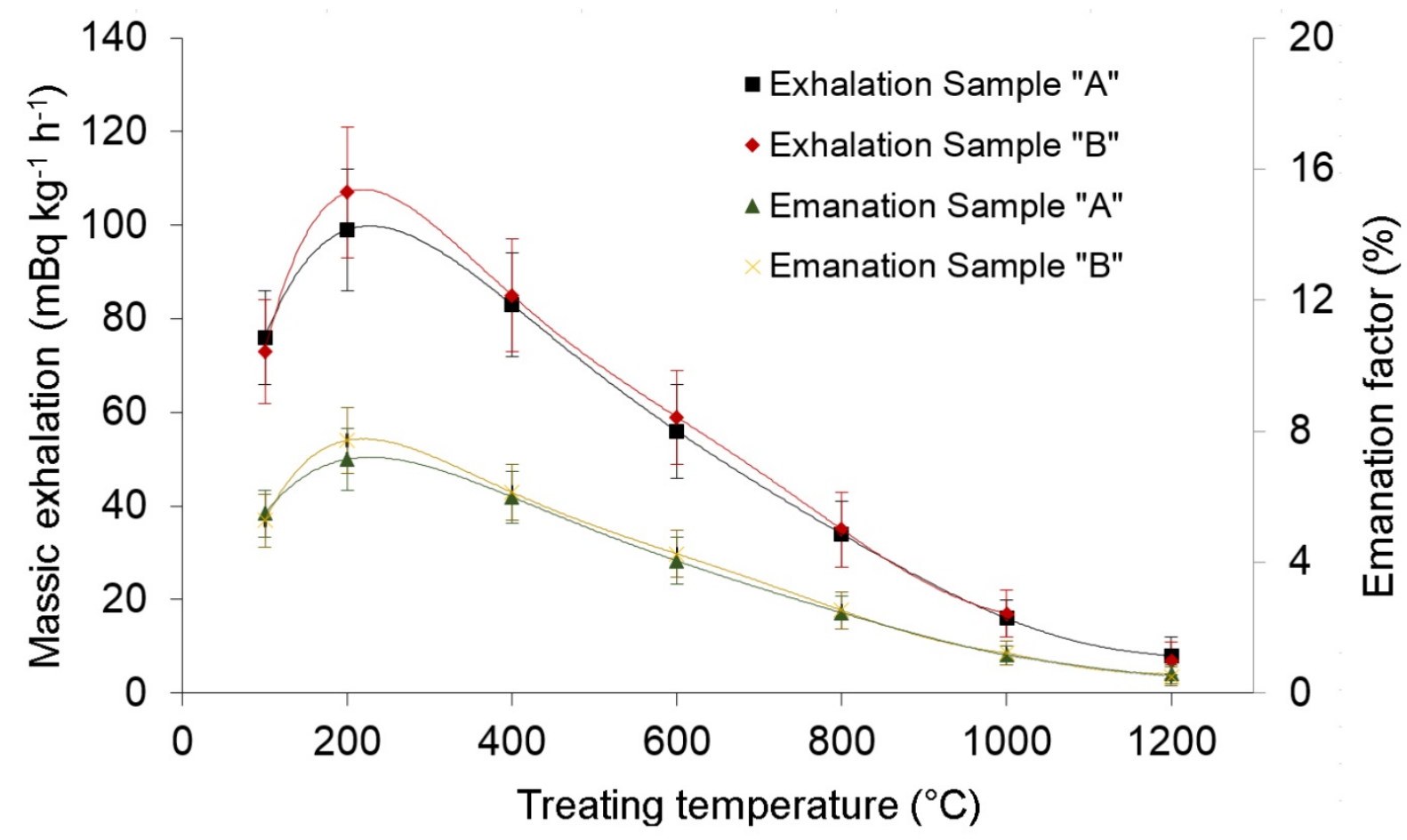


Fig. 2. Massic exhalation and radon emanation characteristic in function of applied heat-treatment temperatures

In a previous study published by Jobbágy et al. 2009 (measurements were carried out in same laboratory of University of Pannonia) the emanation dependency in function of heat treatment were investigated. Despite of the different measurement technique and the red mud sample used by Jobbágy et al. 2009 the characteristic of the emanation curves of both study were very similar. Owing to that fact it can be stated that the thermal behaviour of different red mud samples are similar.

The significant changes in the massic exhalation capacity and calculated emanation factors clearly proved that the internal structure of the heat treated samples changed significantly. For this reason, the comparison of different states of internal structure conditions was necessary to understand the exhalation behaviour of red mud.

\subsection{Internal structural parameters}

The distribution of the pore volume in the function of the pore diameter provided the first approximate explanation (see Fig. 3).

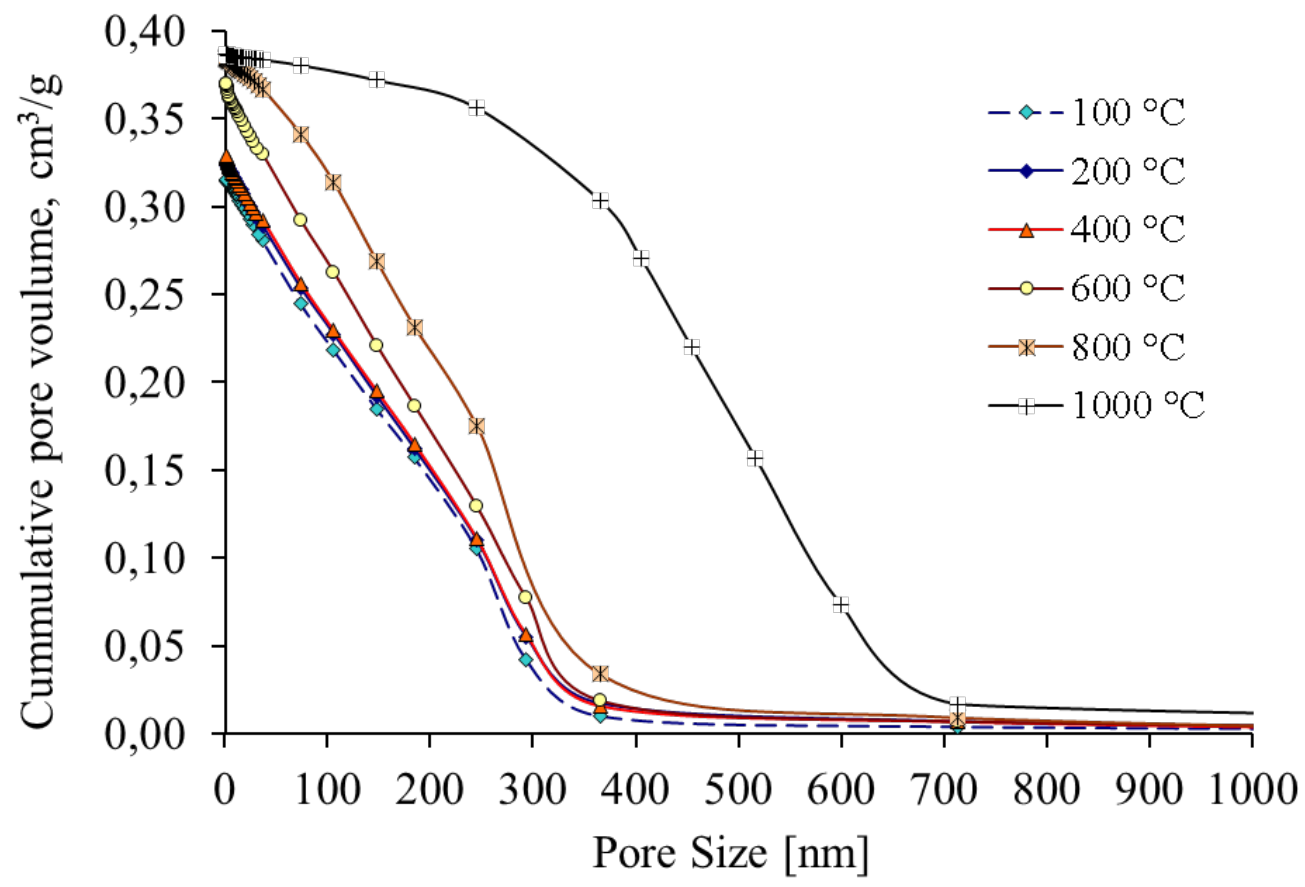

Fig. 3. Cumulative pore volume in function of pore size between 1-1000 nm

The cumulative pore size distribution of the heat-treated samples can be seen. The curves clearly prove that significant differences were found between the porosity features of the investigated samples. The highest total pore volume results were observed in the case of the highest temperature treated samples, where the cumulative pore volume in the function of the pores size shows that in the lower case range $(<100 \mathrm{~nm}$ ), the frequency of the pores was very low. This was assumed to be the reason why the massic exhalation capacities were very low in the high temperatures treatments. 
The abovementioned fact can be prominently observed in Fig. 4, where the cumulative pore volume is illustrated to be between 1.7 to $100 \mathrm{~nm}$. The total pore volume of the $1000^{\circ} \mathrm{C}$-treated samples was more than four times lower than in the $100^{\circ} \mathrm{C}$-treated samples. Therefore, it can be stated that the massic exhalation capacity of the heat-treated samples mainly depended on the total pore volume of the mezzo-pores.

However, a strong correlation was found between the mezo-pores and the massic exhalation features; the elevated massic exhalation capacity in the case of the $200^{\circ} \mathrm{C}$-treated samples pointed to an elevated pore volume range, which also had the biggest effect on the amount of emanated radon and exhaled radon.

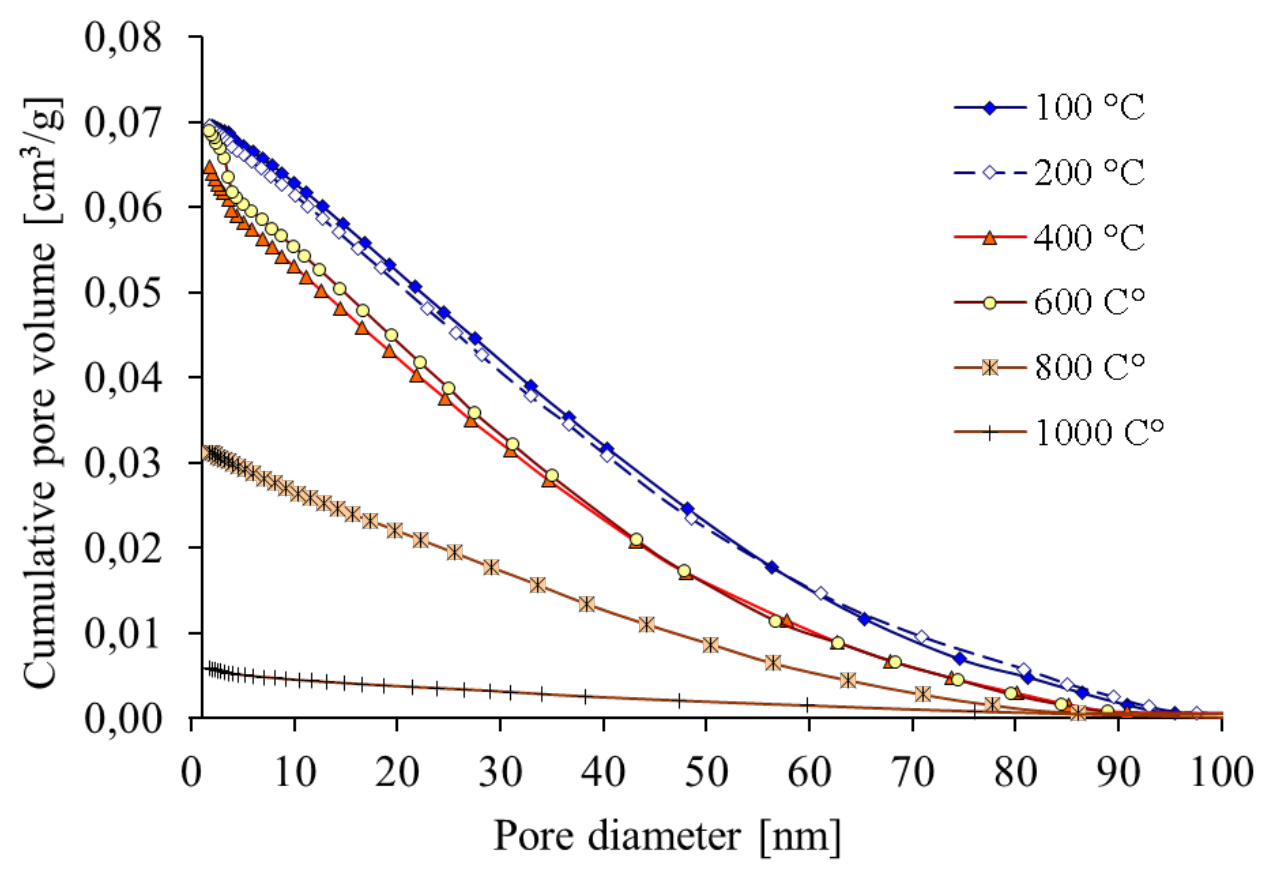

Fig. 4. Cumulative pore volume in function of pore size between 1-100 nm

This elevated pore volume range was found to be between 60 to $90 \mathrm{~nm}$, where the cumulated pore volume was the highest (see Fig. 5). 


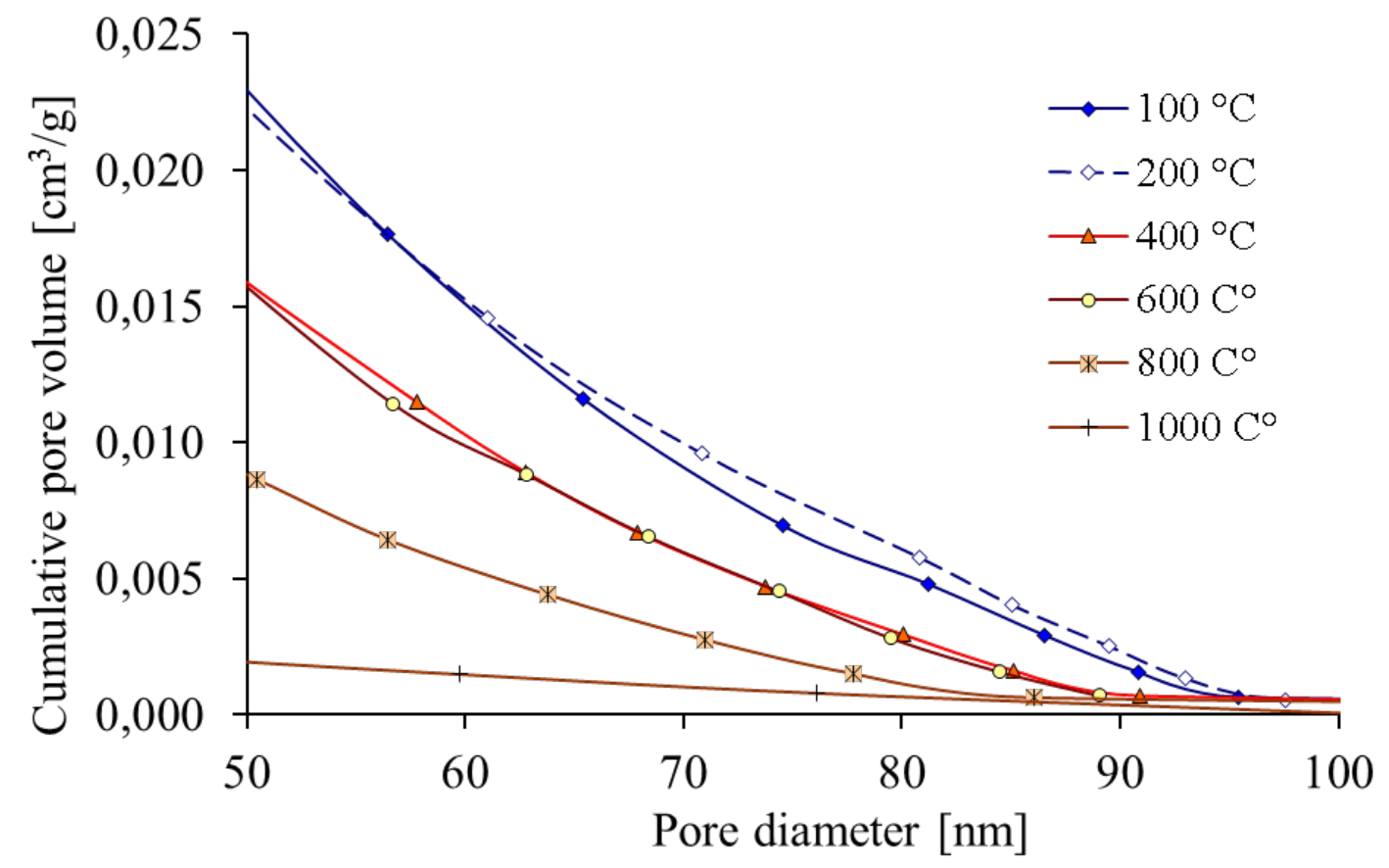

Fig. 5. Cumulative pore volume in function of pore size between $50-100 \mathrm{~nm}$

\subsubsection{Emanation vs. internal structure}

The specific surface of all heat-treated samples and the pore volume were calculated according to BET theory (Brunauer et al. 1938). The obtained results were compared with calculated emanation factors (Fig. 6.) to find connection between them.

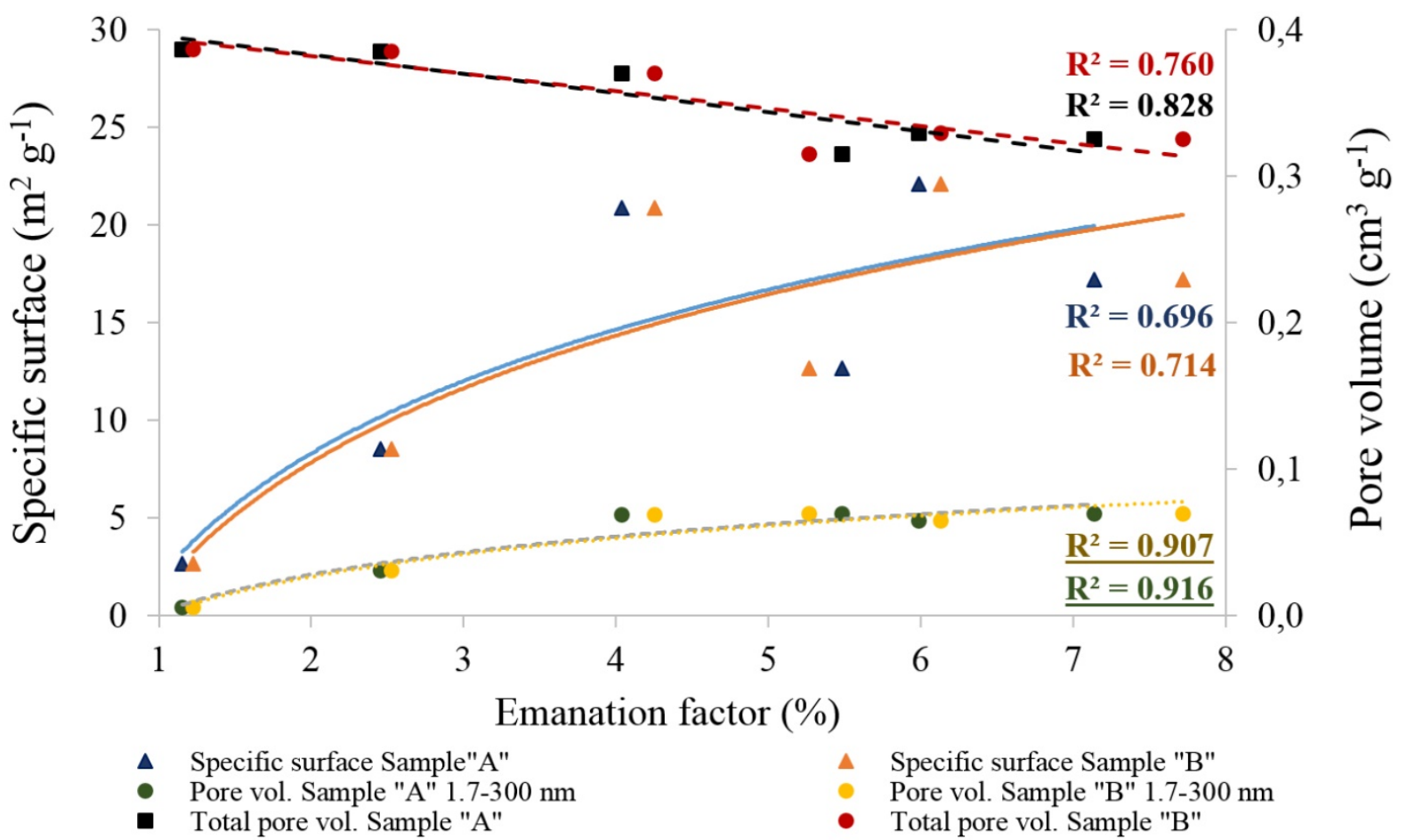

Fig. 6. Pore volume and specific surface dependency from emanation factor 
Strong correlation was found between the mezoporosity $(1.7-300 \mathrm{~nm})$ features and emanation factor as it was expected from cumulative pore size distribution of the heat-treated samples (Fig 3.). Owing to this fact it can be safely stated that the emanation factor greatly depends on the amount of the mezopores in materials. In case of total porosity opposite connection was found with emanation factor. The total volume of the pores had decreasing tendency compared with emanation factor.

Furthermore, the emanation coefficient were also compared with specific surface characteristic of investigated samples. As it was also expected increasing emanation tendency was found in function of increasing specific surface tendency. However, the correlation was not so high compared with mezopores the specific surface measurements can also provide useful information about emanation characteristic of porous media. The slender correlation can be explained with different porosity distribution in the function of applied heat. In case of high temperature range.

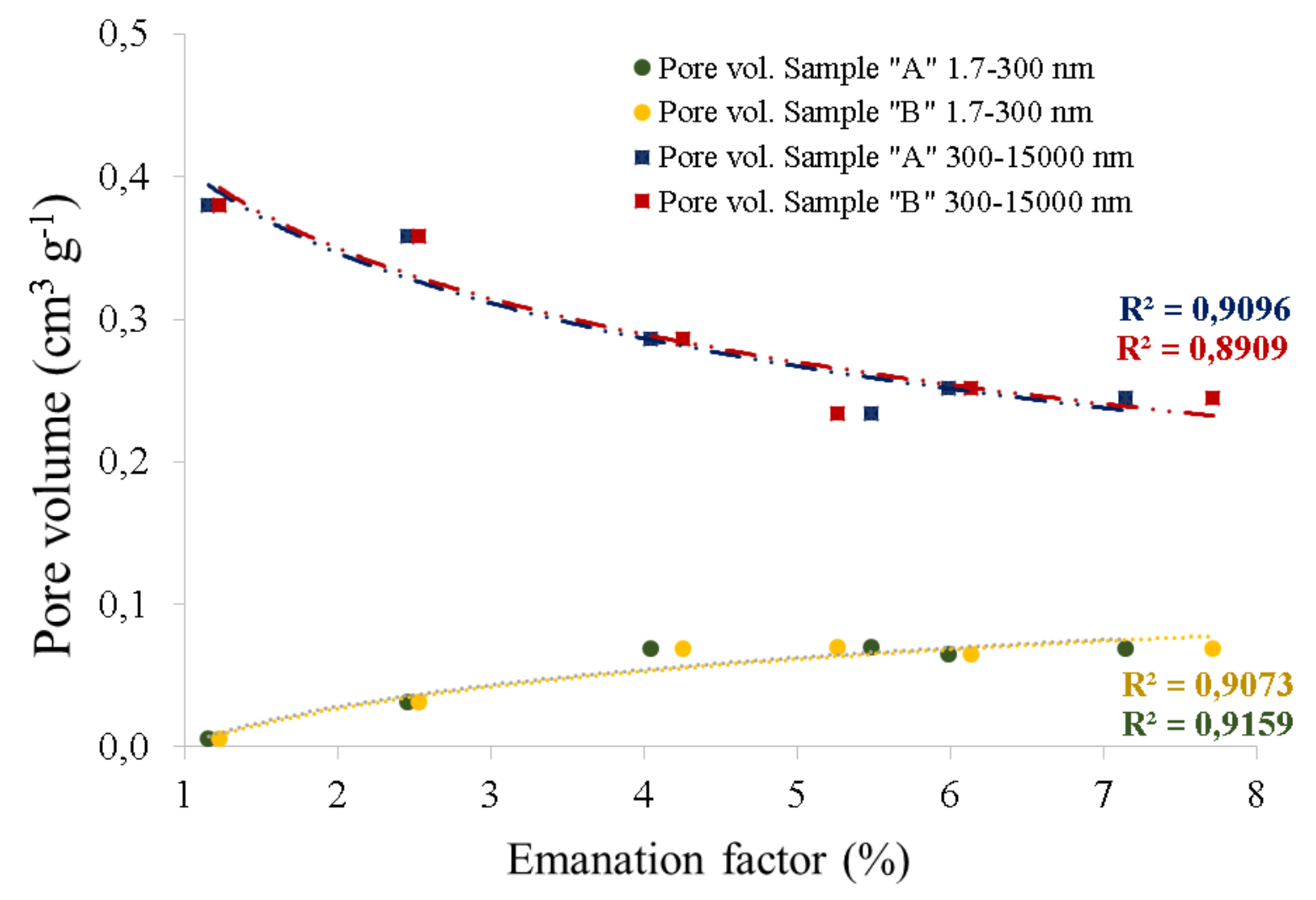

Fig. 7. Micro and mezopore dependency from emanation factor

The micro- (1.7-300 nm) and macro pores (300-15000 nm) were compared in the function of obtained emanation factors as well. The result of the comparison can be seen in Fig. 7. Strong correlation was found with emanation characteristic in case of both parameter. The curves of each pore volume range proved that the micropores disappeared whilst the nanopores of the red mud formed as a result of the heat-treatment. On the basis of obtained results it can be safely stated that the effect of heat-treatment had strong effect on porosity features of the matrix. However, the total porosity of red mud test samples 
had increasing tendency with elevated heat the massic radon exhalation and the radon emanation of red mud decreased. The characteristic of changes can be expressly caused by the decrement of mezopores which were mainly responsible for emanation phenomena.

\subsection{Superficial morphology}

Significant visual differences were observed in the case of the superficial morphology snapshots with 500x magnification and in $600^{\circ} \mathrm{C}$ (Fig. 8/a) and $1000^{\circ} \mathrm{C}$ (Fig. 8/b) treated samples. It can be safely stated that the surface of the samples modified in the case of the higher temperature. Furthermore, the pores also disappeared. The snapshots of the superficial morphology provided visual evidence of the internal structural changes, which can explain the close-up of the pores and as a result the radon exhalation modifying effect of the heat-treatment.

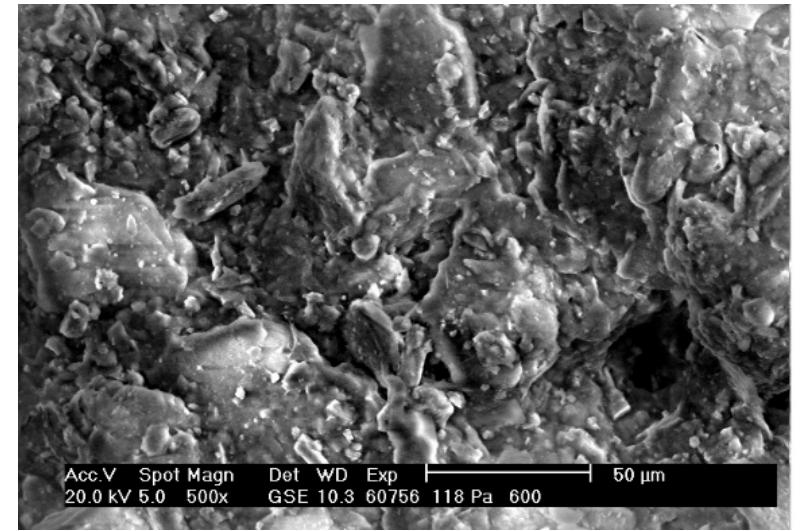

Fig. 8/a. Surface of $600{ }^{\circ} \mathrm{C}$ treated samples

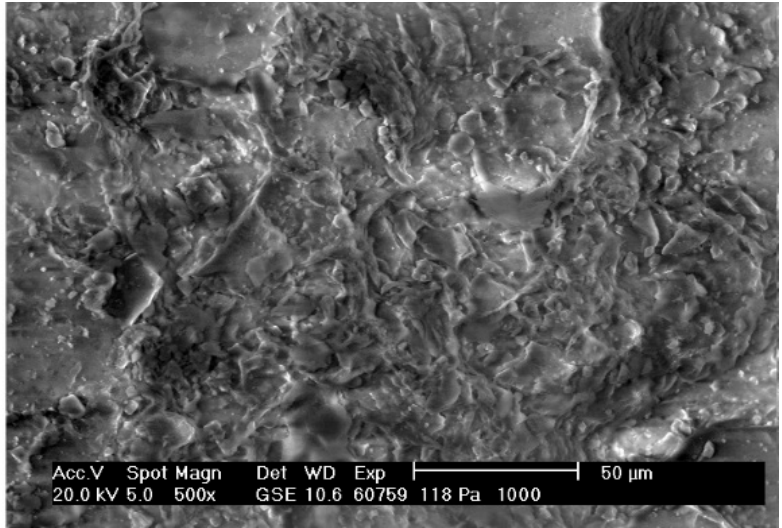

Fig. 8/b. Surface of $1000{ }^{\circ} \mathrm{C}$ treated samples

\section{Conclusions}

On the basis of the results obtained in this study it can be stated that radon emanation and the massic exhaling capacity greatly depends on the applied temperature of the heat-treatment. However, the initial massic exhalation increased as a result of the $200^{\circ} \mathrm{C}$ treatment temperature (lower temperature range). In the higher temperature range between $400^{\circ} \mathrm{C}$ to $1200^{\circ} \mathrm{C}$, the massic exhalation in the samples reduced at a continuous rate. In case of $1200{ }^{\circ} \mathrm{C}$ treated samples the measured massic exhalation was only $10 \%$ of the initial. As such, the heat-treatment had a beneficial effect on massic exhalation from the perspective of the red mud case highlighted previously. A strong correlation was found between the micro porosity and the radon emanation and massic exhalation features. This correlation was based on the obtained pore volume distribution in the function of pore size and the comparison of pore volume in micro porosity range $(1.7-300 \mathrm{~nm})$. It was found that pores under $100 \mathrm{~nm}$ were primarily responsible for the elevated radon emanation and as such, for massic exhalation, too. In the case of the $100^{\circ} \mathrm{C}$ and $200^{\circ} \mathrm{C}$ temperature range, the cumulative pore volume was approximately one magnitude higher than in the 
$1000^{\circ} \mathrm{C}$ treated samples, which was also found to be the case for the massic exhalation profile. Heattreatment can therefore reduce the risk originating from exhaled radon.

Despite these promising results, the mixtures composed of red mud and other matrix components that are used in building material factories must be investigated, since certain components can have an effect on one another, which in turn can cause a potentially harmful final structure.

\section{ACKNOWLEDGEMENT}

This work was supported by the Hungarian State and the European Union projects Grant No. TÁMOP-4.2.2.A-11/1/KONV-2012-0071 and the European Union and the State of Hungary, cofinanced by the European Social Fund in the framework of TÁMOP 4.2.4. A/2-11-1-2012-0001 'National Excellence Program 


\section{References}

Brunauer, S., Emmett, P.H., Teller, E. 1938. Adsorption of gases in multimolecular layer. J. Am. Chem. Soc. 60, 309-319. DOI: 10.1021/ja01269a023

Cosma, C., Cucoş-Dinu, A., Papp, B., Begy, R., Sainz. C. 2013. Soil and building material as main sources of indoor radon in Băiţa-Ştei radon prone area (Romania). J. Environ. Radioactiv. 116, 174-179. DOI:10.1016/j.jenvrad.2012.09.006

Cosma, C., Dancea, F., Jurcut, T., Ristoiu, D. 2001. Determination of ${ }^{222}$ Rn emanation fraction and diffusion coefficient in concrete using accumulation chambers and the influence of humidity and radium distribution. Appl. Radiat. Isot. 54, 467-473. DOI: 10.1016/S09698043(00)00286-4

EN Standard Netherlands Standardization Institute (NEN) Radioactivity measurement 2001. Determination method of the rate of the radon exhalation of dense building materials, NEN 5699:2001 EN (2001)

Gelencsér, A., Kováts, N., Turóczi, B., Rostási, A., Hoffer, A., Imre, K., et al., 2011. The red mud accident in Ajka (Hungary): characterization and potential health effects of fugitive dust. Environ. Sci. Technol. 45, 1608-1615. DOI:10.1021/es104005r

Ishimori, Y., Lange, K., Martin, P., Mayya, Y.S., Phaneuf, M. 2013. Measurement and Calculation of Radon Releases from NORM Residues Technical Reports Series No. 474 International Atomic Energy Agency, Vienna

Jobbagy, V., Somlai, J., Kovacs, J., Szeiler, G., Kovacs, T. 2009. Dependence of radon emanation of red mud bauxite processing wastes on heat treatment. J. Hazard. Mater. 172, 12581263. DOI: 10.1016/j.jhazmat.2009.07.131

Karangelos, D.J., Petropoulos, N.P., Anagnostakis, M.J., Hinis, E.P., Simopoulos, S.E., 2004. Radiological characteristics and investigation of the radioactive equilibrium in the ashes produced in lignite-fired power plants. J. Environ. Radioactiv. 77, 233-246. DOI:10.1016/j.jenvrad.2004.03.009

Keller, G., Hoffmann, B. and Feigenspan, T. 2001. Radon permeability and radon exhalation of building materials. Sci. Tot. Environ. 272, 85-89

Kovács, T., Sas, Z., Somlai, J., Jobbágy, V., Szeiler, G., 2012. Radiological investigation of the effects of red mud disaster, Radiat. Prot. Dosimetry. 152, 76-79 DOI:10.1093/rpd/ncs192

Kovler, N., Perevalov, A., Steiner, V., Metzger, L.A. 2005. Radon exhalation of cementitious materials made with coal fly ash: Part 1 e scientific background and testing of the cement and fly ash emanation J. Environ. Radioactiv. 82 doi:10.1016/j.jenvrad.2005.02.004

Kovler, K. 2006. Radon exhalation of hardening concrete: monitoring cement hydration and prediction of radon concentration in construction site. J. Environ. Radioact. 86, 354-366. DOI: 10.1016/j.jenvrad.2005.10.005

Kovler, K. 2011. Legislative aspects of radiation hazards from both gamma emitters and radon exhalation of concrete containing coal fly ash Constr. Build. Mater. 25, 3404-3409. DOI: 10.1016/j.conbuildmat.2011.03.031

López-Coto, I., Mas, J.L., Bolivar, J.P., García-Tenorio, R., 2009. A short-time method to measure the radon potential of porous materials, Appl. Radiat. Isot. 67, 133-138, DOI:10.1016/j.apradiso.2008.07.015 
Mujahid, S.A., Hussain, S., Dogar, A.H. and Karim, S. 2005. Determination of porosity of different materials by radon diffusion. Radiat. Meas. 40, 106-109.

Petropolous, M.P., Anagnostakis, M.J., Simopolous, S.E. 2001. Building materials radon exhalation rates: ERRICA intercomparison exercise results. Sci. Tot. Environ. 272, 109-118. DOI: 10.1016/S0048-9697(01)00674-X

Pontikes, Y., Nikolopoulos, P., Angelopoulos, G.N. 2007. Thermal behaviour of clay mixtures with bauxite residue for the production of heavy-clay ceramics. J. Eur. Ceram. Soc. 27, 16451649, DOI: 10.1016/j.jeurceramsoc.2006.05.067

Pontikes, Y., Rathossi, C., Nikolopoulos, P., Angelopoulos, G.N., Jayaseelan, D.D., Lee, W.E. 2009. Effect of firing temperature and atmosphere on sintering of ceramics made from Bayer process bauxite residue. Ceram. Int. 35, 401-407. DOI: 10.1016/j.ceramint.2007.11.013

Prasad, G., Ishikawa, T., Hosoda, M., Sorimachi, A., Sahoo, S. K., Kavasi, N., et al. 2012. Seasonal and diurnal variations of radon/thoron exhalation rate in Kanto-loam area in Japan. J. Radioanal. Nucl. Chem. 292, 1385-1390. DOI: 10.1007/s10967-012-1620-6

Quindos, L.S., Fernandez, P.L., Soto, J. 1994. A method for the measurement of the emanation factor for 222Rn in small samples of porous materials. Radiat. Prot. Dosim. 56, 171-173.

Sas, Z., Somlai, J., Szeiler, G., Kovacs, T. 2012. Radon emanation and exhalation characteristic of heat-treated clay samples, Radiat. Prot. Dosim. 152, 51-54. DOI:10.1093/rpd/ncs191

Sas, Z., Somlai, J., Szeiler, G., Kovacs, T. 2015. Usability of clay mixed red mud in Hungarian building material production industry J. Radioanal. Nucl. Chem. In press DOI 10.1007/s10967015-3966-Z

Sglavo, V.M., Campostrini, R., Maurina, S., Carturan, G., Monagheddu, M., Budroni, G. 2000. Bauxite 'red mud' in the ceramic industry Part 1: thermal behaviour. J. Eur. Ceram. Soc. 20, 235-244, DOI: 10.1016/S0955-2219(99)00088-6

Sglavo, V.M., Maurina, S., Conci, A., Salviati, A., Carturan, G., Cocco, G. 2000. Bauxite 'red mud' in the ceramic industry Part 2: production of clay-based ceramics. J. Eur. Ceram. Soc. 20, 245-252, DOI: 10.1016/S0955-2219(99)00156-9

Szabó, Zs., Völgyesi, P., Nagy, H.É., Szabó, Cs., Kis, Z., Csorba, O., 2013. Radioactivity of natural and artificial building materials e a comparative study, J. Environ. Radioactiv. 118, 6474 DOI:10.1016/j.jenvrad.2012.11.008

Trevisi, R., Risica, S., D’Alessandro, M., Paradiso, D., Nuccetelli, C., 2012. Natural radioactivity in building materials in the European Union: a database and an estimate of radiological significance. J. Environ. Radioactiv. 105, 11-20. DOI: 10.1016/j.jenvrad.2011.10.001

Tuccimei, P., Moroni, M. 2006. Simultaneous determination of 222Rn and 220Rn exhalation rates from building materials used in Central Italy with accumulation chambers and a continuous solid state alpha detector: influence of particle size, humidity and precursors concentration. Appl. Radiat. Isot. 64, 254-263. DOI: 10.1016/j.apradiso.2005.07.016

UNSCEAR REPORT 2010. Sources and effects of ionizing radiation, United Nations Scientific Committee on the effects of Atomic Radiation, UNSCEAR 2008 Report to the General Assembly with Scientific Annexes, United Nations ISBN 978-92-1-142274-0

WHO., 2009. A public health perspective, WHO handbook on indoor radon. World Health Organization 
Winkler, D., 2014. Collembolan response to red mud pollution in Western Hungary, Appl. Soil. Ecology. 83, 219-229 DOI: 10.1016/j.apsoil.2013.07.006

Yao, Y., Li, Y., Liu, X., Jiang, S., Feng, C., Rafanan, E. 2013. Characterization on a cementitious material composed of red mud and coal industry byproducts, Constr. Build. Mater. 47, 496-501. DOI: 10.1016/j.conbuildmat.2013.05.030

Zhang, N., Liu, M., Sun, H., Li, L. 2011. Evaluation of blends bauxite-calcination-method, red mud with other industrial wastes as a cementitious material: properties and hydration characteristics. J. Hazard. Mater. 185, 329-335. DOI: 10.1016/j.jhazmat.2010.09.038 